\title{
Theoretical and Practical Possibilities of Lower-Medium-Level Spatial Division
}

\begin{abstract}
The paper is concerned with the theoretical and practical approaches to administrative regionalisation. The authors attempt to present a new methodology, which on one hand is theoretical and from the other, enables the design of an optimal spatial system in terms of the demands of the population. This is presented on through the example of Hungarian districts (the level between municipalities and counties in the administrative system).
\end{abstract}

Keywords: district, spatial division, methodology, accessibility.

\section{Spatial division in scientific thinking}

\section{Theoretical issues of spatial division}

The basis of the examination of spatial research engaged in spatial phenomena is made up in each case by a particular spatial division, which appears as a characteristic given from the beginning in the vast majority of cases. Many studies (Csanádi-Ladányi 1992, Dusek 2001, Forest 2005, Bömermann 2012) prove, however, that the results of research are closely related to spatial division, so they can highlight or disguise the different characteristics excessively. Spatial division, playing an important role in many fields of science, the characteristics of the formation of spatial structures applied in social scientific analyses and public administration is examined in connection with the subject of the paper.

A significant change in Anglo-Saxon social scientific research was brought about by scientific theoretical discussions following World War II, since the emphasis shifted from the principally descriptive analyses earlier on to modelling and the examination of structures and systems (Györi 2005). The questions of spatial division also came to the fore at the time: some researchers wrote entirely theoretical works (Gregory 1949, Haggett 1965, Grigg 1969), while others showed the importance of spatial divisions by highlighting certain aspects of space (Alampiyev 1961, Bunge 1966). There was another change in the approach from the 1970s, since the theoretical and methodological tools of former researchers could not answer the social problems in the world; therefore, widespread criticism was directed at the strongly quantitative approach. Thus, new intellectual trends emerged in scientific theoretical discussions that were rooted primarily in Marxist and 
humanistic ideas (Gregory et al. 2009). The need for and the necessity of amalgamating the different views are increasingly dominant at around the turn of the millennium, which is a task to be solved by the young generation (Barnes 2009).

\section{Boundaries and territorial units}

A task of spatial division is to delineate boundaries according to determined aspects, which thus separate territorial units from one another based on the analysis and classification of similar and different characteristics.

The examination of boundaries was the description and classification of the characteristics of (state) boundaries according to attributes of morphology, nature, origin and history from the end of the 19th century practically to the termination of World War II. The most dominant idea until the 1960s was that natural units are separated by natural boundaries, which, at the same time, means the embodiment of objective reality (Kristof 1959). However, as a result of increasingly intensive scientific theoretical discussions in the middle of the century, a growing number of people questioned from the 1960s and 1970s that boundaries were determined from the beginning, and considered them as social and political constructions as opposed to the earlier supposition. Interdisciplinary research became widespread from the 1980s, and as an effect of stronger post-modern intellectual currents, answering the questions "how?" and "why?" as opposed to hard analyses and the typification of functions came to the fore in examinations. This in turn pointed towards the deeper understanding of the themes of relations, co-operation or identity (Kitchin-Thrift 2009).

According to the present approach in social sciences, neither natural boundaries nor natural territorial units exist (Nemes Nagy 1998, Hajdú 2006), since they are established as a result of classifications by selected objective and subjective criteria. Spatial systems are used as political tools in most of the cases or are the consequences of power or ideological fights, so the structures established merely fix the state of a given moment of these "fights". The boundaries delimiting the many different territorial units are simultaneously the results of existing spatial disparities and in many cases are the cause of the further increase of the differences. For that very reason, epistemological criticism, which relies on the social history of the formation and use of boundaries/territorial units, is indispensable in scientific research (Bourdieu 1985).

\section{Theoretical aspects of spatial division}

As physical and social spaces are not homogeneous, designated points, or delimited territorial units are needed to ensure that as much and accurate information is available as possible for the performance of analysis, control and organisational tasks (Dusek 2004).

Relying on the Anglo-Saxon literature, Tamás Dusek highlights, in respect of spatial division, that each of the elements filling in the area to be divided should be part of the division on one hand, and that every element needs to be classified according to an unambiguous categorisation on the other. In addition, it is indispensable to apply identical criteria in case of multi-level classifications (Dusek 2006). József Nemes Nagy designates three aspects, in relation to the division of space, which have key importance in practice. 
The primary point of view of spatial division is that it should reflect the structures present in reality as accurately as possible. The second point is comparability, which means the necessity of the comparability of territorial data available at different points in time and the need for the stability of spatial systems in time. The third aspect concerns the subject of manageability, which comprises the options for size, cardinality and the aggregation of information (Nemes Nagy 2009).

The emphasis is laid on the possibilities and methods of the formation of administrative spatial division in the study, so the work of István Bibó should be highlighted among the theoretical references. Bibó elaborated an administrative spatial division system in the 1970s, which brought households needs to prominence. When forming the administrative breakdown in this way, top-down organisation operates to a lower and lower extent; the appropriate structure is determined much more importantly by every-day practices and possibilities, and is built from the bottom to the top (Bibó 1986 [1975]). Based on all these, Bibó highlighted that the centres of the different territorial units are ideally located at a distance that can be optimally approached according to households' needs, and the different territorial units should be proportionate to one another for the sake of a balanced administration. In addition, it is necessary to emphasise the unity of physical planning and the coherence of the different territorial levels, as well as to take into consideration the level-difference problematics of practical belonging to an area. In the modelling chapters, considerable emphasis is laid on the achievement of optimal accessibility from the five principles previously outlined.

\section{Theories of public administration organisation in Hungary}

The breakdown and organisation of the state area from an administrative aspect are basically power, political and organisational issues, where national characteristics and the imprints of historical processes also emerge. Public administration is a factor of dominant importance at the levels of both the state and the individual: it covers the life of the population, strongly affects the hierarchy and the development trend of the settlement network and the characteristics of socio-economic movements. This effect, however, is not one-way: the territorial distribution of the population and settlements, transport possibilities, natural conditions or the characteristics of the territorial division of labour, all form the approach and options of public administration organisation (Hajdú 1994).

The settlement network does not make up a homogeneous system, many settlements capable of performing central functions were formed in certain areas of the country, while, for example, areas with small villages having less than one thousand inhabitants fight the problems of a lack of towns. A settlement becoming a centre brings about many institutions and functions, so even if the new centre rises higher in hierarchical levels, it cannot develop primarily in the process of urbanisation (Beluszky 2005). Although proportionality among the many different territorial units is a basic need in forming an optimal breakdown, differences in the sizes (physical extension, population number) of settlements and functionally coherent areas raise questions that are difficult to eliminate.

In addition to the effects of the settlement network, transport and accessibility also play an important role in forming public administration. In the course of the 20th century, the importance of transport initially emerged in county-level planning (Prinz 1933, Vagács 
1952) and urban analyses (Erdősi 1985, Bajmócy-Kiss 1999). In this interpretation, there is a direct relationship between the attraction of towns and transport options, which emphatic emphasis should be laid in territorial planning. Even though info-communication and technological development since the turn of the millennium have rewritten territorial processes, the analysis of their impact on public administration is of limited significance in the literature.

In the following, three public administration organisation approaches that emerged in the 20th century will be presented. These had a significant effect not only on the practice of spatial division in Hungary but also reflect dominant ideologies and political efforts at the same time.

The elaboration of the landscape administrative principle is related to the name of Pál Teleki in Hungary. As according to the objective spatial approach of Teleki, "real" geography is landscape geography, which results from the inter-connection of natural geography and anthropogeography. His administrative analysis following the peace treaty of Trianon was prepared to take into consideration the nationality, natural, social, economic, transport and settlement-network characteristics in Greater Hungary. The division elaborated this way could not be of practical use owing to the reduction in the area of the country, but the followers of Teleki, adopting the approach, continued and applied the landscape-geographic approach. Following World War II, the landscape geographic and administrative approach was driven into the background in Hungary, and the economic factor came to the fore in the organisation of society as a consequence of political and ideological changes (Hajdú 2005).

Economic zoning was based on taking into account the characteristics of the conditions of production and the territorial division of labour (Beluszky 1987). Economic spatial structure forms a homogeneous system according to Marxist ideology: natural resources form the basis, and the different branches of production are established relying on this. The distribution of population is not homogeneous, consistent with these two factors, but is tightly associated with the characteristics of production; furthermore, the settlement network is closely related to the territorial distribution of population and the characteristics of production. Public administration does not form a single sphere in this approach but covers the components of economic structure, and thus enters into relation with the total natural, social and economic system (Krajkó 1989). The effort to highlight the economic sphere was present all through the period of socialism, which, interwoven with changes, shows up in today's administrative thinking after losing its exclusivity during the years of transition.

The theory of economic zoning considers the economic sphere as the basis of administrative breakdown, while the theory of central places designated the conditions of supply as the starting point of the organisation of society. The concept considers the settlement network's structural and functional relation system as the framework that delineates complex urban areas serving as grounds for public administration (Hajdú 2006). The approach came to the fore predominantly in the 1980s, which is apparent in that the breakdown by districts, abolished in 1983, changed urban neighbourhood administration at the lower-medium level of public administration in Hungary. This new form of administration aimed to create the unity of towns and villages so that the settlements 
belonging to one urban neighbourhood be designated by the types of relationships making up the daily space of population movement (Beluszky 1987).

Though in today's administrative-territorial organisation, the urban area approach is the most dominant one of these, all the three schools of thought form spatial thinking. It is also important to underline this because no optimal administrative territorial breakdown exists in itself. The judgement of territorial breakdown mainly consists of how much the established structure is suitable for reaching current political purposes (Hajdú 1987).

\section{Classical social scientific methods of spatial division}

The division of physical space can be established serving many different functions, and so needs to meet various requirements. Spatial structures applied in scientific research or statistical data collections have other characteristics than those in administrative structures, having a basic role in social management - therefore the methodologies of the divisions also offer different paths.

The simplest procedure is the geometrical method, according to which the centres of the area to be divided are pre-given, while the boundaries of districts are designated by perpendicular bisectors on the lines linking neighbouring points. In case the different centres have differing active force, perpendiculars need to be drawn on lines linking neighbours at points shifted depending on the magnitude of active force (Nemes Nagy 1998).

The geometrical method can be applied when the purpose is to project the information, measured in distinct points, to the whole space. Although this was used in certain practices and in setting up spatially statistical structures (Mezencev 2010), it is not suitable for delimiting optimal territorial breakdowns. Specifically, it does not take into consideration other spatial organisation processes since the primary determinant of setting up a breakdown is the spatial position of available centres and their relation to one another.

Another method is the determination of urban areas, where the possible centres are first selected, and then the areas belonging to them are delimited. The question of designating centres rarely emerges in the Hungarian literature (Bajmócy-Kiss 1999, KissBajmócy 2001); settlements having higher functions, including administrative breakdowns, gain the central role. The issue of the central role is relatively deeply discussed only in studies on administrative reforms (Beluszky 1987, Faluvégi 1994, Szalkai-Jakobi 2011, Szalkai 2012). Urban areas are determined with the aid of the gravity model, which calculates the boundaries of urban areas using weights assigned to centres and the distance between two centres. Although functional districts belonging to centres can be delimited with the aid of the gravity model, this method also does not meet certain criteria of spatial division (proportionality, comparability) in several respects; namely, it highlights disproportionalities and inequalities in the settlement network (Nagy 1996).

The third possibility for spatial division is offered by the method of cluster analysis. It is the elements of the area to be divided that are classified in cluster analysis, and this is completed by the spatial dimension. Thus, a cluster can include elements that show similar features not only in respect of socio-economic indicators, but also meet the neighbourhood criterion from the point of view of location (Kabai 1981). Despite expectations, this method is not optimal in practice, since often, many groups with low numbers of elements and a 
few with large numbers are created at a time, which raises the problem of spatial disproportionality (Nemes Nagy 2005).

It is important to highlight that, in addition to the presented three possibilities of spatial division, new methods have emerged; principally following the turn of the millennium, which are built mainly on the results of computer science (Fallah et al. 2009, FarahaniHekmatfar 2009). With the development and availability of computer technology, as well as the opening of the different fields of science towards one another, the set of tools of social scientific research can be extended with methodological solutions that can lead to entirely novel results, opening the possibilities of examination in a wider spectrum. In the following chapters, this paper aims to present this. It is pointed out through theoretical and practical examples the new solutions that the application of a computer scientific set of tools can offer in the question of administrative spatial division besides the previously mentioned classical methods.

\section{Models and algorithms}

This chapter explores what applied mathematical, statistical and computation theoretical tools can be used to model spatial division, and within this, the problem of the delimitation of lower-medium-level administrative units through the re-establishment of the district system in Hungary.

In creating the model, the principles of Bibo (1986 [1975]), and the structural relationship system of the settlement network through accessibility by public roads were considered as the primary theoretical aspects of the administrative spatial organisation. Two models were established on the basis of these aspects. The paper shows possible ways of solving these, their actual implementations on computer, and, in possession of the results, examines their applicability to the original spatial division problem.

\section{Applicability of facility location problems in spatial division}

The purpose of problems known as facility location in the English literature is to determine the place of certain resources (facilities) so the costs of satisfaction of the demands for the resources should be minimal, while location meets certain conditions. Both the resources to be located and the criteria to be satisfied can be various, so the range of problems belonging to this category is also wide. As one will see, decisions on the siting of facilities often requires the simultaneous consideration of several aspects that might be conflicting. Thus, the problems to be solved - in both traditional and computation theoretical senses set difficult tasks for decision makers. As a result, the issue has been the subject of countless studies from the second half of the 20th century to date (Farahani-Hekmatfar 2009).

The location set covering problem (LSCP) is a version of the set covering problem - a classical problem of computation theory - used in facility location, where the number of located resources and the costs of their location should be minimised so that all the demand for the resources should be satisfied. Its condition is that in no case should the resource fall farther from the demand to be served than a designated parameter of distance (ToregasReVelle 1972). To serve all emerging demand can be a purpose when, for instance, locating 
services that can be used in case of emergency, allocating aircrew, or in case of services provided by the public sector, those which should be accessible for all citizens (Toregas et al. 1971, Fallah et al. 2009).

\section{Application of LSCP to establish districts}

Based on the Bibó principles, the optimal accessibility of the centres of spatial units needs to be considered, with the fit of units to one another especially important from the theoretical aspects of administrative spatial division. In addition, it is an evident point of view that all should have access to the services provided by public administration. One version of LSCP is applied for these aspects in the first model. Optimal accessibility is modelled by the distance parameter. ${ }^{1}$ A minimum sub-set of settlements (centres) is searched, with the selection of which, a centre can be found for every settlement within the particular area (generally a county, taking into account the fit to one another) from which it is not farther than the value of the distance parameter.

For the solution, the set covering problem is formulated as a "binary integer programme," in which the variables of the target function to be minimised can be one of the $\{0,1\}$ values:

$$
\min \sum_{\mathrm{j}=1}^{\mathrm{n}} \mathrm{x}_{\mathrm{j}}, \mathrm{x}_{\mathrm{j}}=\left\{\begin{array}{l}
1, \\
0,
\end{array} \text { if } \mathrm{j}\right. \text { is otherwise a centre. }
$$

Thus, the purpose is the selection of a minimum number of centres out of the $n$ settlements in the area, meeting the condition,

$$
\sum_{j \in N_{i}} x_{j} \geq 1, i=1,2, \ldots, n, N_{i}=\left\{j \mid d_{i j} \leq D\right\} n,
$$

i.e. we need to find for every settlement $i$ a centre $j$, for which the distance $d_{i j}$ between these two is lower than the pre-defined distance parameter $D$.

"NP", the optimisation version of set covering, belongs to difficult problems. It is a class of computation theory problems, the solution of which - expressively - takes much time, and this time increases sharply along with the growth of the size of the problem.

Therefore, two groups of algorithms have been developed to solve such problems. One of the groups, although guaranteed to find the optimum, can require an unrealistically high running time in case of large problems, while "approaching algorithms" produce in less time a result on which it can be proved that it differs from the optimum only to a defined extent.

In the cases the paper seeks to solve, the size of the problem (typically some hundreds of settlements) was such that "branch and bound," one of the algorithms searching the optimum, produces a result in a reasonable time; using this provides the possibility to find the optimal solution.

The model was run on the tool specialised in binary integer problems (bintprog()) of the Optimization Toolbox of MATLAB software. This tool is suitable for solving $\min \mathrm{f}^{\mathrm{T}} \mathrm{x}$

1 The distance parameter is considered to be pre-given here, we are not concerned with its definition, but a recommendation concerning its actual value can be found in the work of Miklós Oláh and András Csite (2011). 


$$
\mathrm{A}_{\mathrm{x}} \leq \mathrm{b}, \quad \mathrm{A}_{\mathrm{eq}} \mathrm{x}=\mathrm{b}_{\mathrm{eq}}
$$

form problems, where ( $)^{\mathrm{T}}$ indicates the operation of transposition, $f, b$ and $b_{e q}$ are vectors, $A$ and $A_{e q}$ are matrices, and the elements of $x$ can equal 0 or $1 .^{2}$ Thus the condition on the distance parameter needed to be reformulated, so that it should comply with these criteria. $A$ was simple to form having the $\mathrm{d} \in \mathrm{R}^{\mathrm{nxn}}$ matrix, containing the distances between settlements on public roads, relevant to a particular area:

$$
A_{i j}=\left\{\begin{array}{c}
-1, d_{j i} \leq D \\
0, d>D .
\end{array}\right.
$$

(The negative sign is needed because of the direction of the relation during the inversion of indices because of transposition.) The other two parameters equalled $f_{1,2, \ldots, n}=1$ and $b_{1}$, $2, \ldots, \mathrm{n}=-1$ values. The problem in such form could be solved with the above-mentioned tool.

The elements of the produced result vector $x$ correspond to the elements of $X$ in the original formulation of the problem. Therefore, they indicate whether particular settlements are given a central role in the optimal solution.

In addition to the selection of centres, it was also important to delimit districts. Bearing in mind optimal accessibility every settlement was annexed to the centre closest to it, so forming for every centre $j$ the set of settlements belonging to it:

$$
\mathrm{S}_{\mathrm{j}}=\left\{\begin{array}{r}
\left\{\mathrm{k} \mid \mathrm{d}_{\mathrm{kj}}=\min \left(\left\{\mathrm{d}_{\mathrm{kl}} \mid \mathrm{X}_{\mathrm{l}}=1\right\}\right)\right\}, \mathrm{X}_{\mathrm{j}}=1 \\
0, \mathrm{X}_{\mathrm{j}}=0 .
\end{array}\right.
$$

This model can be completed in several ways. The following examines a case in which the need arises that on establishing districts, not only their minimum number should be taken into consideration, but also minimising the size of the population forced to commute to the district centre.

In case no other aspect occurs, the task can be solved with one version of the method described previously. The size of commuting population can be minimised most simply within a particular area (county) if the population of settlements designated as district seats is maximised or - as the algorithm used carries out the minimisation of the target function the target function is weighted in inverse proportion to population numbers. Thus, the binary integer programme form of the task changes as follows:

$$
\begin{gathered}
\min \sum_{j=1} \frac{x_{j}}{p_{j}}, \\
\sum_{j \in N_{i}} x_{j} \geq 1, \quad i=1,2, \ldots, n, \\
N_{i}=\left\{j \mid d_{j i} \leq D\right\}, x_{j}= \begin{cases}1, & \text { if } j \text { is otherwise a centre, } \\
0, & \end{cases}
\end{gathered}
$$

where $p_{j}$ indicates the population resident in a particular settlement. Besides this, we continue to take into account the condition that for every settlement a district centre lying

2 Though we did not need the stipulations on the equation in this case, e.g. the situation, in which one wishes to select certain settlements by all means as district centres, could have been readily modelled by this. 
not farther than the distance parameter must be identified. One solution is with the optimisation toolbox $\mathrm{f}_{\mathrm{j}}=\frac{1}{\mathrm{p}_{\mathrm{j}}}$, and the conditions of inequality are unchanged.

However, the purpose cannot only be the minimisation of the population forced to commute - it may also arise as a more complex aspect that should take into consideration, in addition to the size of the population, the distances to cover while commuting. This means that the solutions are preferred in which - with a minimum number of districts and a maximum size of population in district centres - districts can be established so that their population should cover as small a distance as possible when commuting to the district centre. Nonetheless, this raises two opposite requirements: the minimisation of the distance from district centres would imply the reduction of the size of districts while the minimisation of the number of district centres would entail its growth.

\section{Multi-objective optimisation model - minimising commuting population and distance of commuting}

The first model and its modified form both originated in searching the optimum place of a single function. However, there are cases similar to the previously discussed one, when optimising more than one target functions at a time. This results in a "multi-objective optimisation task", in which the global optimum places of the target functions are not common, they contradict one another. This implies that instead of a single optimal solution there is only a set of solutions, out of which the actually suitable one can be selected based on some further aspect stemming from the original problem raised.

The group of genetic algorithms includes methods that - taking an idea from biological evolution - create a population of possible solutions in the course of all steps (generations), i.e. the "goodness" of more than one entity, that which means a possible solution at the time is examined with a valuation function. Afterwards, a new population is established by selecting the entities that proved to be good. This can be completed by mutation, i.e. a certain degree of randomised change of entities, the combination of two or more entities (parents), or the transfer of the best entities from the previous generation to the next one. Because of selection, the average goodness of the population increases from generation to generation, so it approaches the optimum.

However, the disadvantage of genetic algorithms is that it cannot be established from the result whether it is the actual global optimum of the target function. Although the size of the covered part of the solution space can be enlarged by increasing the size of the population and the number of generations, the optimality of the solution obtained cannot be proved, so decision on its suitability is only possible when one knows the original problem.

Many versions of genetic algorithms exist with which multi-objective optimisation problems can be solved (Binh-Korn 1996, Poloni et al. 1996, Kalyanmoy 2001, RobičFilipič 2005). In the present work, one version of the NSGA-II algorithm is applied (Kalyanmoy et al. 2000) since this is available in MATLAB software's Global Optimization Toolbox, i.e. the toolbox usable for global optimum search problems. 
In solving the problem, the aim was to have a minimum number of districts at the same time so as to minimise both commuting population and the total distance covered by them while commuting. The optimum place was searched for in the following expressions:

$$
\begin{gathered}
\min \sum_{j=1}^{n} x_{j}, \\
\min -\sum_{j=1}^{n} p_{j} x_{j}, \\
\min \sum_{j=1}^{n} \sum_{k \in S_{j}} p_{k} d_{j k}, \\
\sum_{j \in N_{i}} x_{j} \geq 1, \quad N_{i}=\left\{j \mid d_{j i} \leq D, 1 \leq \mathrm{j} \leq \mathrm{n}\right\}, x_{j}=\left\{\begin{array}{l}
1, \text { if } j \text { is otherwise a centre. } \\
0,
\end{array}\right.
\end{gathered}
$$

Thus, we minimise the number of districts $\left(X_{j}\right)$, maximise the population of settlements having a central role $\left(P_{j}\right)$, and minimise in every district the sum of the distances between the settlements belonging there $\left(S_{j}\right)$ and the centre, weighted with their population. Set $S_{j}$ is formed in every iteration according to what was described for the former model. The functions thus generated are used as valuation functions during the run of the genetic algorithm. ${ }^{3}$ A simpler way of enforcing the stipulation on distance parameter $D$ was not available as in the case of solving binary integer programming problems. Instead, the values of all the three target functions were considered $+\infty$ in the points of the solution space not meeting the stipulation.

It was found that the convergence of the algorithm was further speeded up if, before its run, the size of the problem was reduced. For this, the possible district centres are ordered by size, then - starting with the smallest - such a number of elements are removed from them with which the remaining ones can still "cover" all the settlements in the area within the particular distance parameter. The size of the parameter vector of the target function is thus identical to the number of the remaining settlements.

To further highlight the central role of larger settlements, it was also established in the following version of the model, in which the number of districts and the size of commuting population were dependent on the population of district centres (they were divided by this). The target functions, in this case, were modified as follows:

$$
\begin{gathered}
\min \sum_{j=1}^{n} \frac{x_{j}}{p_{j} x_{j}}, \\
\min -\sum_{j=1}^{n} p_{j} x_{j}, \\
\min \sum_{j=1}^{n} \frac{\sum_{k \in S_{j}} p_{k} * d_{j k}}{p_{j} x_{j}} .
\end{gathered}
$$

In the model thus generated, other aspects are damaged because of the big role of the population in the district centers: more and smaller districts are created.

3 Thus a centre belongs to its district, too, but this does not change the value of the target function, since the distance of a settlement from itself is zero in the matrix of accessibility on public roads. 
In the practical application of the genetic algorithm, many problems occurred. Due to the character of the algorithm, it cannot be proved that the results obtained are equivalent with the global optimum of the target functions. Because of the finite computing capacity available, a compromise concerning the accuracy of the algorithm was required in order to be able to keep run time within reasonable limits. Three tools (Table 1) were applied to adjust accuracy; the actual values of these parameters are as follows:

Parameters of genetic algorithms and their values

Table 1

\begin{tabular}{l|l} 
Size of populations & 500 \\
\hline Number of generations & 500 \\
\hline Number of maximal "unchanged" generations & 100
\end{tabular}

The role of the size of populations and number of generations is clear in enhancing accuracy, while the number of "unchanged" generations adjusts when reaching a deadlock: in case the algorithm cannot "move away" from the deadlock after a particular number of iterations, it stops running. By applying the algorithm to the same problem many times repeatedly, subjectively, good results applicable to the original problem were obtained; in case of the parameter values in Table 1, even within a runtime of a few minutes. Out of the Pareto-optimal results obtained, those with a minimum number of districts were selected. In addition, despite the stochasticity of the algorithm, the results of the repeated runs were the same or differed from one another only in the number of equivalent solutions with a minimum number of districts. Therefore, concluding the optimality of the results thus obtained.

\section{Comparison and evaluation of models, further possibilities}

Table 2 shows the disparities between the outcome and the run time of the different models, applying them to the settlements of Veszprém County and a distance parameter of $30 \mathrm{~km}$.

The results in the table were obtained on a computer with Core i7 processor and $8 \mathrm{~GB}$ of memory, run under Ubuntu Linux 12.04 operating system. The version of the MATLAB software used for the solution was 7.12.0.635 (R2011a). In case of the models solved by integer programming, the bintprog() tool was used.The run of the genetic algorithm was completed by gamultiobj() tool, ensured by the already mentioned Global Optimization Toolbox. In case of the latter, calculating the goodness of the entities of the current population can be readily paralleled; taking this into account, this parallel execution was permitted, which ran in 8 (the same number as the number of processor cores) parallel processes. 
Results of applicable models and their characteristics

\begin{tabular}{|c|c|c|c|c|c|}
\hline $\begin{array}{l}\text { Model; } \\
\text { algorithm }\end{array}$ & $\begin{array}{l}\text { Number of } \\
\text { districts }\end{array}$ & $\begin{array}{c}\text { Population in } \\
\text { district } \\
\text { centres, } \\
\text { persons }\end{array}$ & $\begin{array}{l}\text { Commuting } \\
\text { population, } \\
\text { persons }\end{array}$ & $\begin{array}{l}\text { Weight of } \\
\text { commuting }\end{array}$ & Runtime, sec \\
\hline $\begin{array}{l}\text { Unweighted model; } \\
\text { BIP, branch-and-bound }\end{array}$ & 5 & 44351 & 312222 & $\begin{array}{r}5043 \\
279.48\end{array}$ & 0.186 \\
\hline $\begin{array}{l}\text { Maximisation of population in district } \\
\text { centres; } \\
\text { BIP, branch-and-bound }\end{array}$ & 7 & 88817 & 267756 & $\begin{array}{r}4013 \\
709.20 \\
\end{array}$ & 0.236 \\
\hline $\begin{array}{l}\text { Minimisation of weight of commuting; } \\
\text { NSGA-II }\end{array}$ & 7 & 84057 & 272516 & $\begin{array}{r}3762 \\
672.30 \\
\end{array}$ & 327.204 \\
\hline $\begin{array}{l}\text { Minimisation of weight of commuting } \\
\text { and emphasis on large settlements; } \\
\text { NSGA-II }\end{array}$ & 9 & 177527 & 179046 & $\begin{array}{r}2314 \\
897.03\end{array}$ & 262.239 \\
\hline
\end{tabular}

The table clearly reflects how the aspects arising during the different modifications of the problem are considered in the different algorithms. In most of the cases, it was found that the minimum number of districts could mostly be achieved by applying the unweighted model, since the structural aspects of settlement and public road networks are not damaged; this ensures the optimality of the location of centres. Furthermore, it can also be seen that in case of the multi-objective optimisation model run without emphasising large settlements, and by selecting out of the Pareto-optimal solutions, that with a minimum number of districts, the role and goodness of the other two target functions (populations in district centres and weights of commuting) are lower. Their values hardly differing from those of the model aiming at minimising population in district centres. The number of the commuting population and thus the weight of commuting could be best minimised by emphasising large settlements. However, this implies that many settlements in a better position from the aspect of accessibility on public roads could not have the role of a district centre, so a kind of fragmentation can be observed: more and smaller districts needed to be established in order to meet the distance parameter.

\section{The lower medium administrative level of Hungary reflecting on the models}

After reviewing considerations on spatial division and computation theoretical feasibility, the characteristics of lower-medium level were examined, the use of theories in practice and the applicability of models to Hungary.

Two possible methods of spatial division and centre choice were reviewed, which meant the implementation of the algorithms presented in the previous chapter. Choice between the models was made depending on the optimisation principles of spatial division. From a theoretical point of view, the "unweighted" model established by applying LSCP and the "weighted" model implemented with the aid of the genetic algorithm ideal was considered.

In case of the unweighted model, the establishment of spatial units that are optimised from the aspect that the average distance between settlements and their centres should be minimal within "districts" is required, while no settlement can be farther than that given in 
the distance parameter, which changed. This model is, therefore, unweighted, since it does not take into account the population number of either centres or the settlements to be categorised. At the same time, it leaves out of consideration the extent to which the infrastructural conditions necessary to establish district centres are available in a particular settlement. That is, it considers every settlement equal, and only makes a rule that the location of centres should be optimal from the point of view of the public road network and that counties could be covered with as few districts as possible along with the completion of the particular distance parameter. This is an ideal solution from a theoretical aspect, which selects centres based only on the access distance.

The model was run with the maximum permitted travel distances of between $20 \mathrm{~km}$ and $40 \mathrm{~km}$, in line with the former considerations (Szalkai 2012). The map illustrates the centres of the $30 \mathrm{~km}$ model (Figure 1).

District centres for maximum travel distances of $30 \mathrm{~km}$ (unweighted model)

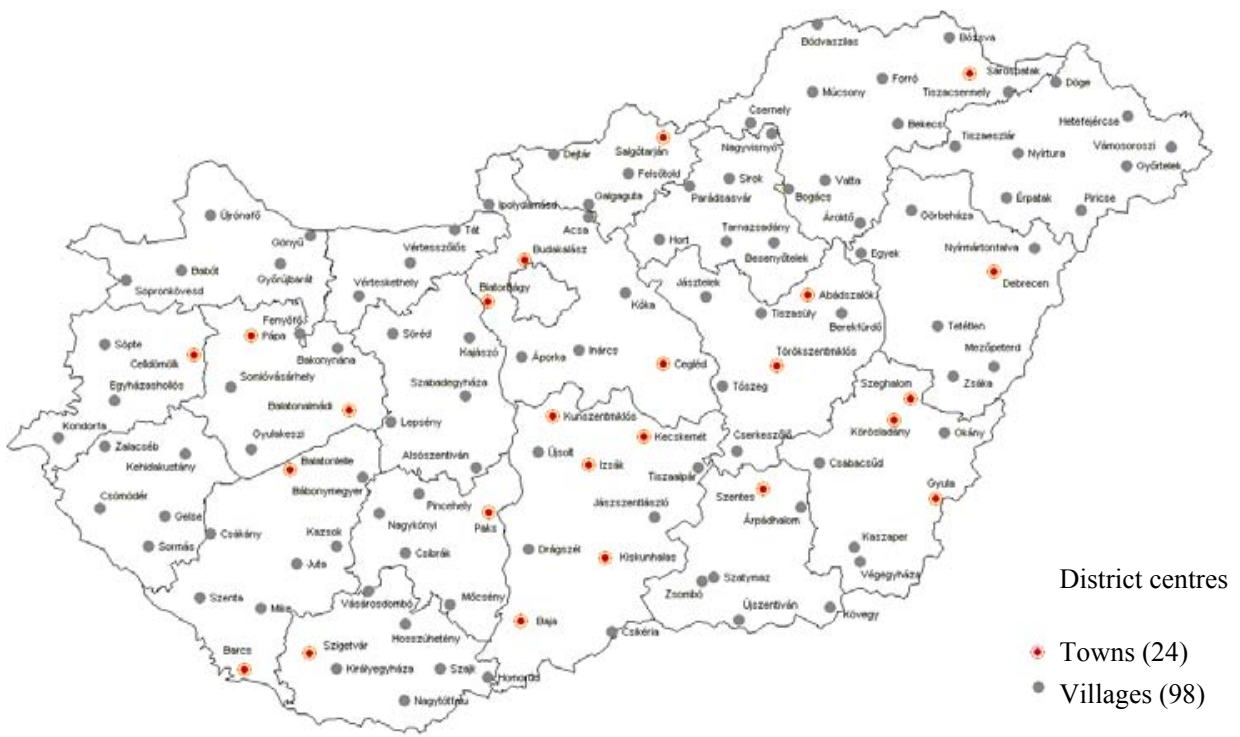

Resulting from the characteristics of the algorithm the idea that the model selects settlements other than those at the top of settlement hierarchy as centres was proven. Out of the total 122 seats, only 24 are of town rank, and merely three of the county seats (Kecskemét, Salgótarján and Debrecen) would become district centres if this theoretical solution was realized. The capital city would also be left out of the centres; Budapest would only be one settlement in the Budakalász district. Similar results are obtained by applying the other two distance parameters; the majority of settlements becoming centres are of village rank, they only emerge from the settlement network due to their location in space and the public road network.

After applying this unweighted model, which was first of all from a theoretical aspect important, there were - by using the genetic algorithm - spatial divisions established, which could be applied from a practical point of view as well. The purpose was to establish 
districts in which the travel distances weighted with the number of the population forced to travel to reach district centres are minimised. In an extreme case, it can be achieved if all settlements are made district centres, i.e. the value of travel distance is 0 . Certainly, this is not a realistic solution, so - as already referred to - the minimisation of the number of districts also needs to be targeted. That is, two parameters with opposite effects should be optimised at a time, which is not possible. Thus, the algorithm applies an intermediary solution: taking into account both aspects at a time it tries to find Pareto-optimal solutions, knowing that the value of none of the parameters can be further improved without worsening that of the other. At last, the algorithm selects from the possible solutions those with a minimum number of districts. From the results, the model permitting maximum travel distances of $40 \mathrm{~km}$ is presented (Figure 2).

Figure 2

District centres for maximum travel distances of $40 \mathrm{~km}$ (weighted model)

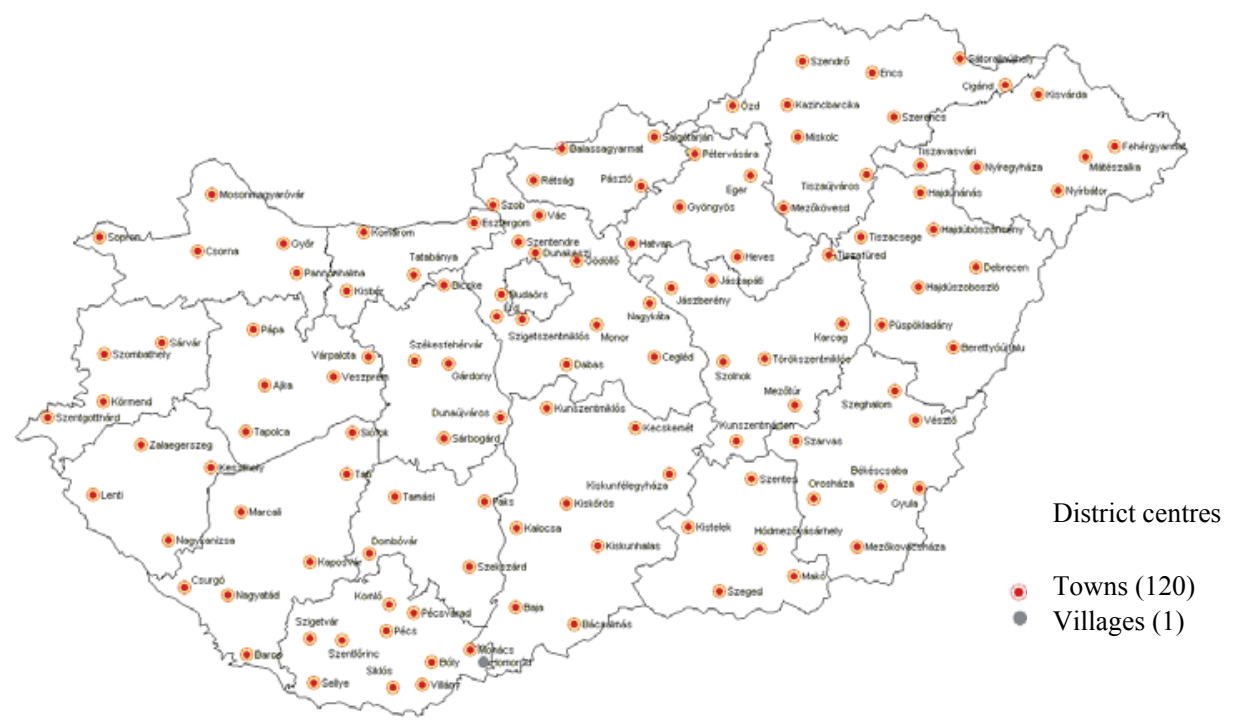

The reason why this model was chosen is, that from the point of view of the number of the spatial units (districts) it can be best compared to the formerly presented unweighted $30 \mathrm{~km}$ model: 122 districts were established, compared with 121 here. The basic difference is that, owing to weighting with population, almost exclusively major elements of the town network become district centres in this case.

The $10 \mathrm{~km}$ difference between the two models, permitted for reaching district centres, is hardly reflected in the number of districts (elements). The reason for this is the better position of villages in space: to have almost the same number of elements, i.e. the same level of supply, smaller distances would be covered if district centres were villages. However, these settlements cannot ensure the required infrastructure, so the weighted model is closer to reality by all means. 


\section{Differences in breakdowns by districts and micro-regions}

Districts were re-established in Hungary on 1 January 2013, 30 years after their abolition. With the increasing timeliness of the topic, several studies were published in Regional Statistics, in the last three years, the authors summarise the history and the situation of lower-medium level and spatial administration, as well as the scientific theoretical approaches to the issue (Miklóssy 2011, 2012, Ivancsics-Tóth 2012, Faluvégi 2012). The methodology applied in establishing districts differed from the models presented here; it was replaced by complex indicators for district centres and then indicators of the level of supply with public administration services (Szalkai 2012), which are in relationship with the presented method through population numbers.

The centres determined in the new breakdown mainly came from among the most populous settlements; in respect of the number of units, the system of districts differs by only one from the system of micro-regions in effect at the time of planning the districts and comprising 175 areas. ${ }^{4}$ Namely, Budapest, which is an undivided, single micro-region in the breakdown by micro-regions, and is not part of the present analysis. This way, the centres of the 174 micro-regions outside the capital and of the 175 districts largely coincide with each other, although the differences have marked spatial characteristics (Figure 3).

Figure 3

\section{Differences between centres of micro-regions and districts}

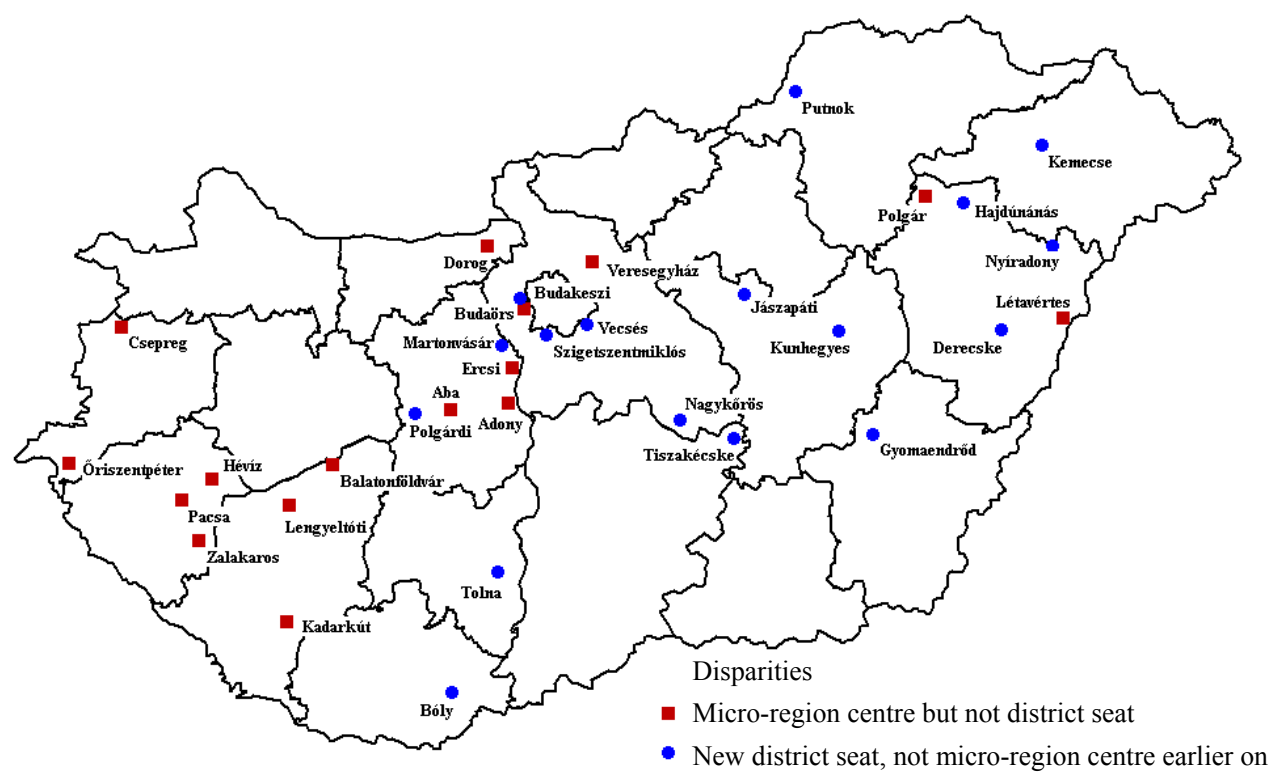

There are 17 settlements which newly obtained a central role. Consequently, 16 earlier micro-region seats did not become district centres at the same time. The two groups are

4 Act CCVII of 2012 effected (one) change compared to the former breakdown by micro-regions from 1 January 2013: enhancing correspondence with the system of districts, it changed the name of the Ercsi micro-region to Martonvásár microregion, and extended its area with Kajászó. 
well separated in space; the majority of the settlements "left out" are located in Transdanubia, while the new district centres can be found principally in the eastern part of the country.

Ignoring the role played by national and local political interests in the changes of the settlements left out of the group of centres, Budaörs is the largest, with nearly 30 thousand inhabitants, while the population of the smallest district centre does not even reach 2,000. Based on the number of "settlement-level administrative functions," which was at last the only aspect of the professional designation of district centres, the elimination of Dorog can be explained to the lowest extent. (The settlement has 12 of the possible 15 functions.)

Leaving out of consideration these two conspicuous cases, the most suitable settlements became district centres, and based on the complex centre order indicator (Szalkai 2012) applied earlier, the next more than ten settlements, not qualified as district centres, are in Pest county. However, the majority of these partly sub-urban, partly commuter settlements will be properly served by the district offices to be established. Nevertheless, in case of smaller settlements having fewer functions, the exclusion of certain settlements from or their inclusion in district centres can be questioned.

In several cases, there is no spatial relationship between new district centres and nondistrict-centre micro-region seats, while new centres were established clearly with the intention of replacement in certain areas. The relocation of centres affected at the same time the group of attracted settlements, though not only splits of micro-regions but also transfers of other settlements between areas occur in such cases (Figure 4).

Change in classification of settlements by micro-region and district breakdowns

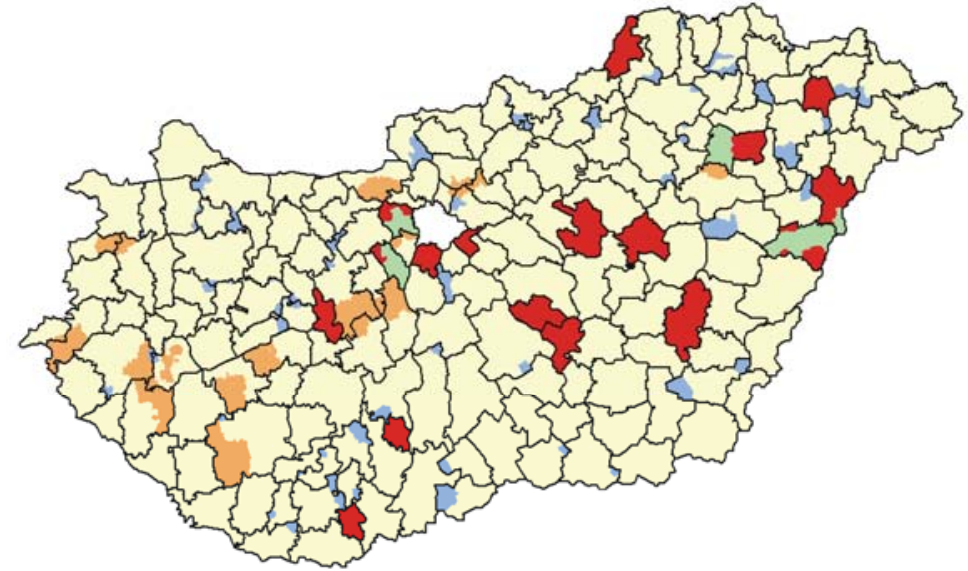

Situation of settlements

Micro-region centre did not district centre, transferred to other, formerly also central settlement (175)

Transferred to new district centre established to replace micro-region centre (28)

Centre exchange (both old and new centres existed formerly) (110)

Micro-region centre and district seat identical $(2,712)$

Transferred to newly established district centre (128) 
The relocation of centres, i.e. the fact that although the former micro-region centre did not become a district centre, a new district centre close to it was designated to replace the micro-region centre, occurs in four cases among the differences between micro-region and district systems. That is how Martonvásár-Ercsi, Budaörs-Budakeszi, Polgár-Hajdúnánás, as well as the trio of Nyíradony, Derecske and Létavértes can be coupled. The settlements indicated in green were transferred to a new centre this way, while there were such settlements (indicatied in red) transfered to every similar districts, whose centres became a district center, but the legislator transfered this settlements to the neighbouring new districts.

Contrarily, because of the "drawing off" of their centres, certain settlements would be too far from new district centres, therefore, they were classified not to the new but to a neighbouring, old centre.

Several larger areas, mainly in Transdanubia, also belong to this same category (indicated in orange) since the most centre losses fall in this area. However, geographically and totally sporadically situated are the 110 settlements indicated in blue (with a population of 170 thousand people) whose micro-region will be a district centre at the same time, yet these villages were classified to another centre that had existed formerly.

Nonetheless, despite the changes, it is clear that the two lower-medium-level breakdowns are dominated much more by similarities than by differences; some $86 \%$ of our settlements belong to the same seat in the district as in the micro-region system earlier on.

The district breakdown established did not classify settlements to the closest centre in all cases. One of its cases is when settlements "could not be" annexed to the closest centre because of the location of county boundaries, so several settlements lie closer to a district centre that can be found not in its own county (Figure 5).

Distance of own district centre in case of settlements ideally attracted by another county

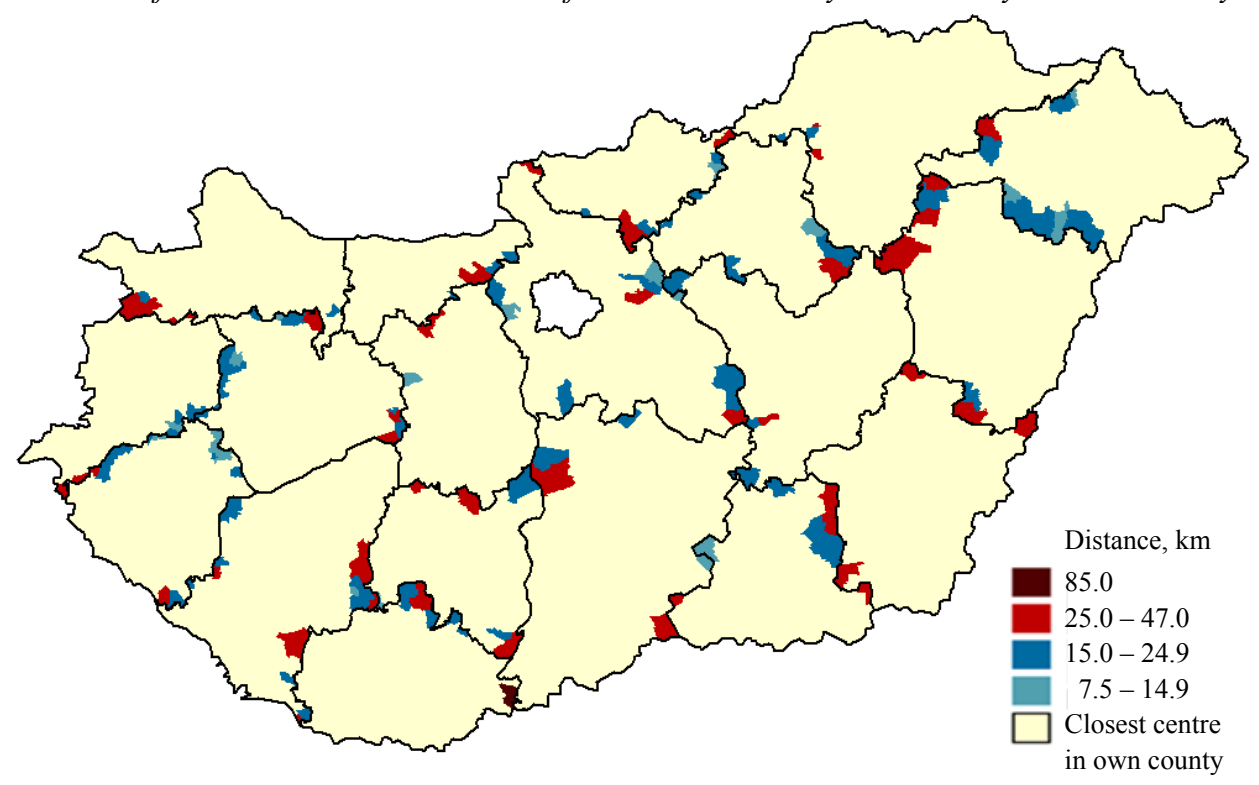


Out of the 219 such settlements comprising 300 thousand people in total, a settlement in a special situation in Southern Hungary is in the worst situation: if the ferry at Mohács is not in service, the district seat can only be reached with a detour of $85 \mathrm{~km}$. Leaving this out of consideration, however, there are settlements that lie farther than $40 \mathrm{~km}$ from their district centre. Not considering county boundaries would affect the most luckily Egyek, belonging to Balmazújváros, since it lies only $13 \mathrm{~km}$ from Tiszafüred.

It deserves even more attention if the above train of thought is mapped at the level of districts, i.e. the group of the settlements is examined that do not lie closest to their own district centre, despite the fact that the closest centre is also within the county (Figure 6).

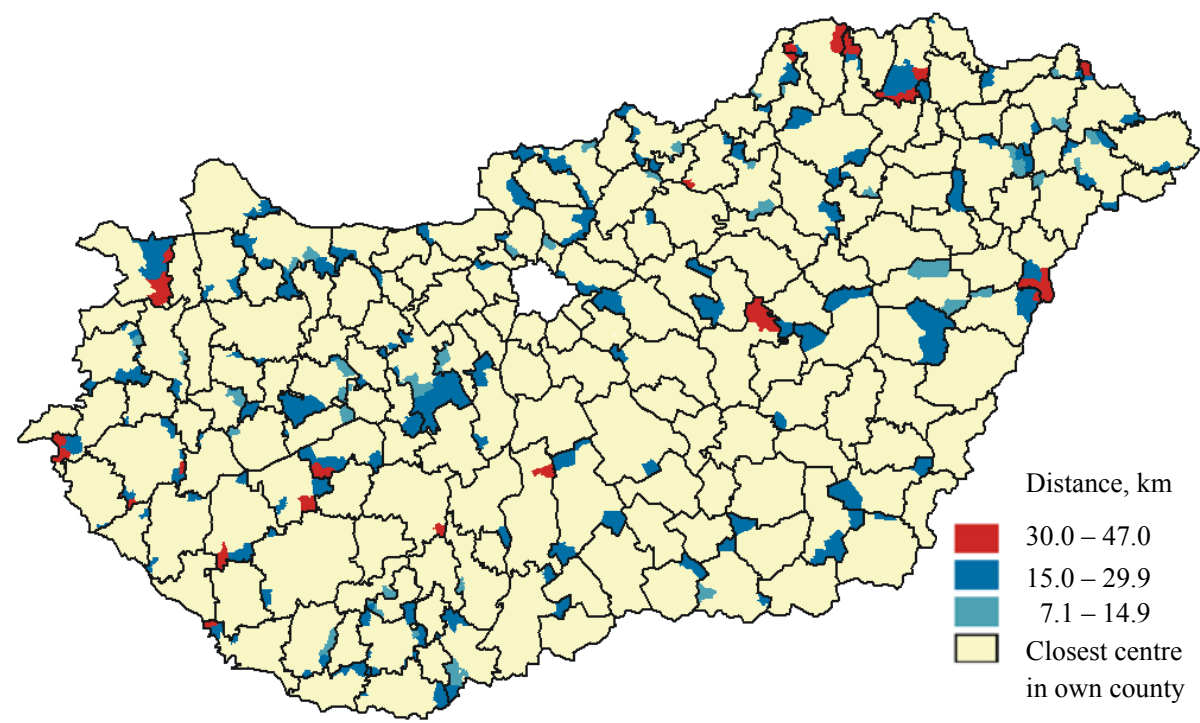

This phenomenon already concerns 365 settlements with nearly half a million inhabitants, although the breakdown established is better for part of this population than as if the closest centre had been taken into consideration; commuting relations point towards the district centre. This can be seen both in the eastern part of the Sopron district and the southern part of the Székesfehérvár district. In contrast, the district breakdown is burdened by serious mistakes as in the case of border-side settlements near Debrecen, and especially in the Gönc district; here a settlement was classified to a centre of nearly the same size despite the fact that it lies $22 \mathrm{~km}$ closer to another, larger centre, and commuting is also observed in this direction. The Gönc district became the least favourable lower-mediumlevel unit of the country from this point of view, the average travel distance weighted with the population forced to travel to the district centre is the highest here, nearly $18 \mathrm{~km}$. In contrast, the same value is below $1 \mathrm{~km}$ - considering district centres points - in the mostly concentrated Debrecen district.

Thus, the settlement network strongly determines the distribution of population within districts: the units having a large town as a centre show a favourable picture even if more 
distant settlements also belong to the central town. Contrarily in areas with smaller centres and with a lack of towns, there is a high proportion of people living far from the centre (Figure 7).

This value is the highest in four eastern Hungarian districts (Balmazújváros, Gönc, Edelény, Nyíradony), and in the two former the micro-regions that were extended just along the boundaries farthest from the centre. In national terms, 122 settlements lie farther than $30 \mathrm{~km}$ from their centre, comprising a population of 86 thousand. Thus, the $30 \mathrm{~km}$ objective as laid down in a government decision of 2011 was mostly fulfilled in total, yet, if one wishes to be accurate, the district breakdown adopted can only be considered - even disregarding the problem at Homorúd - as a $47 \mathrm{~km}$ model. Namely, that is the distance between the settlement in the most disadvantageous situation and its district centre.

Proportion of population living farther than $30 \mathrm{~km}$ from the district centre

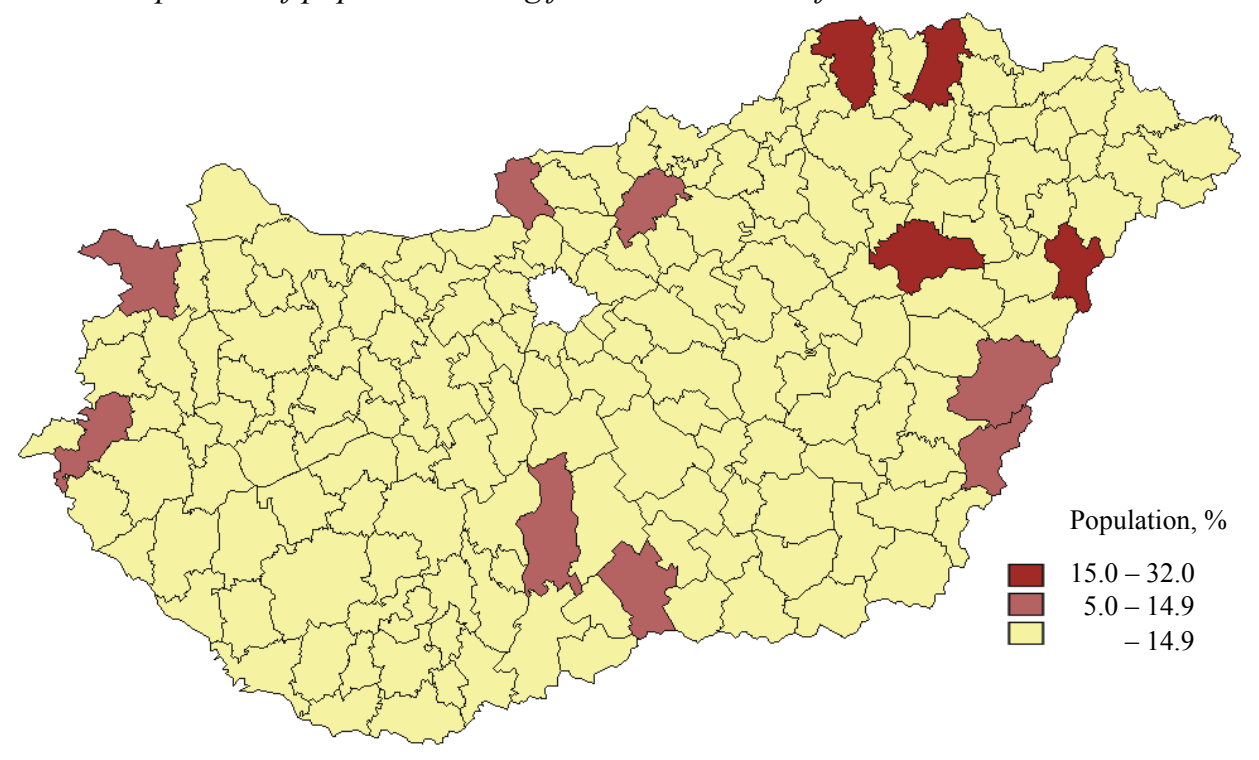

Comparison of model results and existing breakdowns

The analysis of spatial features, as well as the review of the statistical characteristics of the different versions, provides help for a deeper understanding of models and real spatial divisions. The characteristics of the two existing, micro-regional and district breakdowns, as well as six district models, are presented (Table 3).

The spatial division options in the table can be compared to one another in numerous ways. If the starting point is existing breakdowns, it can be stated that district and microregional breakdowns hardly differ from each other, the district system can be considered minimally better from the point of view of concentration: a higher proportion of the population live in the centre or within striking distance to it. From this point of view it deserves attention that the $30 \mathrm{~km}$ weighted model, which best approaching the real spatial division, has almost the same values (50\% weight of central population), but it is achieved together with low distance value, but with an increase in the number of districts. 


\begin{tabular}{|c|c|c|c|c|c|c|c|}
\hline 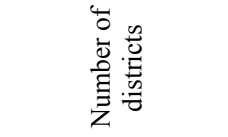 & $\stackrel{n}{\Xi}$ & $\approx$ & $\tilde{I}$ & $\stackrel{8}{\circ}$ & $\stackrel{\text { q }}{\text { q }}$ & $\bar{\Xi}$ & $\widetilde{\sigma}$ \\
\hline 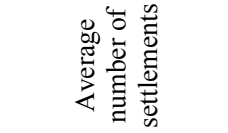 & $\begin{array}{cc}0 & - \\
\infty & \infty\end{array}$ & $\stackrel{\sim}{\tilde{q}}$ & $\begin{array}{l}\infty \\
\text { wi } \\
\text { c. }\end{array}$ & $\stackrel{-\infty}{\rightarrow}$ & $\stackrel{\circ}{\ddot{g}}$ & ڤై & $\stackrel{+}{\dot{b}}$ \\
\hline 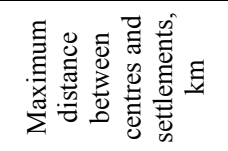 & 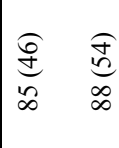 & $\stackrel{\leftrightarrow}{\dot{q}}$ & $\stackrel{\circ}{\dot{m}}$ & iे & 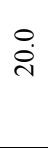 & $\hat{\text { mे }}$ & $\stackrel{\circ}{\dot{m}}$ \\
\hline 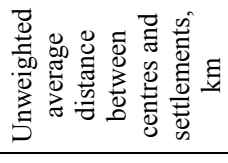 & $\begin{array}{ll}\stackrel{0}{ \pm} & + \\
\dot{I}\end{array}$ & $\stackrel{\stackrel{i}{N}}{ }$ & $\stackrel{t}{\stackrel{t}{6}}$ & $\stackrel{n}{m}$ & $\stackrel{\infty}{\stackrel{0}{\oplus}}$ & 苗 & $\stackrel{\mathrm{I}}{\mathrm{I}}$ \\
\hline 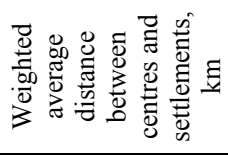 & Gे $\stackrel{+}{\stackrel{+}{*}}$ & $\stackrel{\infty}{a}$ & $\stackrel{ナ}{ \pm}$ & $\overline{\mathrm{I}}$ & $\hat{\infty}^{2}$ & $\ddot{a}$ & $\stackrel{\infty}{6}$ \\
\hline 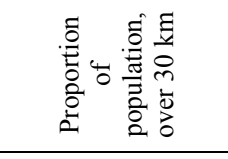 & 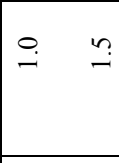 & $\begin{array}{l}b \\
\stackrel{0}{a}\end{array}$ & $\stackrel{0}{0}$ & $:$ & $\stackrel{0}{\circ}$ & $\stackrel{n}{i}$ & $\stackrel{0}{0}$ \\
\hline 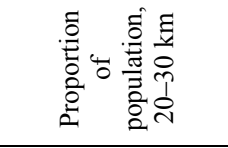 & $\begin{array}{cc}n & m \\
\sim & a\end{array}$ & $\stackrel{\vec{m}}{\dot{m}}$ & $\begin{array}{l}\infty \\
\text { ch } \\
\text { d. }\end{array}$ & $\stackrel{+}{=}$ & $:$ & $\stackrel{\stackrel{\Xi}{\Xi}}{\leftrightharpoons}$ & $\stackrel{\infty}{6}$ \\
\hline 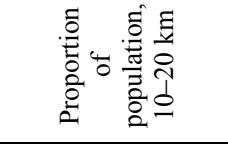 & $\begin{array}{cc}\text { ñ } \\
\text { nे }\end{array}$ & $\hat{\sim}$ & $\stackrel{?}{\stackrel{f}{f}}$ & $\stackrel{n}{\stackrel{n}{n}}$ & $\overrightarrow{\vec{q}}$ & $\hat{\dot{\rho}}$ & $\stackrel{\circ}{\infty}$ \\
\hline 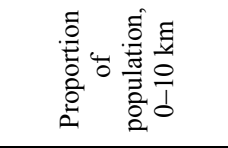 & 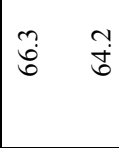 & $\overrightarrow{9}$ & 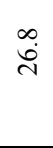 & $\overline{\dot{m}}$ & iे & 节 & ถู่ \\
\hline 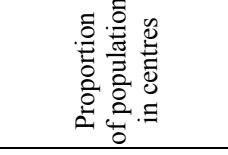 & $\begin{array}{ll}\hat{i} & \hat{\sigma} \\
\dot{\sigma}\end{array}$ & $\vec{\infty}$ & $\stackrel{n}{0}$ & $\stackrel{n}{=}$ & 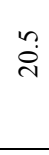 & $\stackrel{n}{+}$ & $\hat{\dot{q}}$ \\
\hline 总产 & 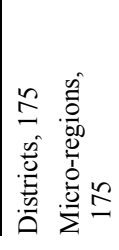 & & & & & 送 & 吾 \\
\hline
\end{tabular}


All the other models move in the direction of deconcentration, and especially those unweighted. The low proportion of population in centres follows from the basic attribute of those since mostly villages with low population size are located in spatially optimum places. The proportion of population in centres decreases to $8 \%$ in case of the $40 \mathrm{~km}$ model while one can witness interesting realignment within the different distance zones. In the 20 $\mathrm{km}$ model with 243 elements, representing the most detailed breakdown in the analysis, the proportion of the population is still high in inner-most zones due to the high density of centres and to distance limits. i.e. large towns "cannot" fall far from villages lying in good positions from a spatial point of view. However, if the permitted travel distance is increased, zones concentrating population move farther from centres, and more than half the population would already live farther than $20 \mathrm{~km}$ from centres in the $40 \mathrm{~km}$ unweighted model. This refers to the fact that places optimal from the point of view of networks are specifically not located close to large towns in this breakdown.

As a result of this, but principally because of the lowest number of districts, average distance values are the highest in this model; at the same time, it deserves attention that nearly 50 fewer district centres would need to be delimited in case of this $40 \mathrm{~km}$ model than in the case of the weighted $40 \mathrm{~km}$ model. The same difference in case of the $30 \mathrm{~km}$ limit is even clearer.

As for average size, the fulfilment of the Bibó principles also needs to be touched on. As models ruled that optimal accessibility should be achieved, districts cannot meet the criterion of proportionality. So there are large differences in the system with respect both to the number of settlements in districts and to population number and area. The districts consisting of the fewest settlements were established in Hajdúság ${ }^{5}$, each of the

Hajdúböszörmény and Debrecen districts consists of two settlements only while the Zalaegerszeg district comprises 84 settlements. From the point of view of population number, district sizes in the breakdown range from below ten thousand to a quarter of a million inhabitants.

\section{Summary}

In the urban area examinations, computerised implementation of theoretical and practical spatial delimitations that optimise the assignment of settlements to centres from different aspects was carried out. Taking into account Bibó's principle of optimal accessibility, the solved task was simpler in computation theoretical terms, determining centres by minimising travel distances, and also a more complex, multi-objective optimisation task.

The result of the first model calculation, with no practical relevance though interesting theoretically, is that the position of settlements in the settlement hierarchy does not follow from the position in the road network space. A good position in the road network does not mean a clear advantage, which means as well that the location of towns is not optimal from the point of view of settlements surrounding them.

In the case of the more complex model, the search was for the common optimum of travel distance, the number of the population forced to travel to centres and the number of territorial units. By shifting the result towards real feasibility - following from weighting 
with population - almost exclusively, the major elements of the town network became district centres in this case.

As a result, the values of average distance - between centres and the attracted settlements - in the two models largely depend on weighting. The distance weighted with the population forced to travel, and the unweighted distance are nearly the same in case of the first model, while the weighted average distance is only the half of the unweighted one for the second model (so in case of real spatial divisions, too). The difference between the two values clearly reveals that the division is favourable for the majority of the population, certainly for the urban population. However, in the peripheries, there remained several poorly supplied areas, which have also been the focuses of economic and social depression to date.

In the district system, set up on 1 January 2012, 122 settlements - comprising a population of 86 thousand inhabitants - lie in a distance exceeding $30 \mathrm{~km}$, a recommended upper limit, from its centre. However, the unfavourable situation of these settlements is partly abated by the system of "government windows", the number of which is intended to be increased to about 300 by the end of 2013. That is, in addition to the 174 district centres (outside the capital) government windows will operate in a further 100 plus settlements on the basis of registration offices. This group will include Budaörs and Dorog, the two biggest losers of the district breakdown, while the district system left $86 \%$ of the settlements in an unchanged position compared to the micro-region system.

\section{REFERENCES}

Alampiyev, P. M. (1961): The objective basis of economic regionalisation and its long-range prospects. Soviet Geography 1 (11): 64-74.

Bajmócy, P. - Kiss, J. P. (1999): Megyék, régiók és központjaik - Modellek tükrében. Tér és Társadalom 13 (1-2): 3151 .

Barnes, T. J. (2009): „Not only...but also”: Quantitative and critical geography. The Professional Geographer 61 (3): 292-300.

Beluszky, P. (1987): A középszintü igazgatás és hazánk térszerkezete. MTA Regionális Kutatások Központja, Pécs.

Beluszky, P. (szerk.) (2005): Magyarország történeti földrajza I. Dialóg Campus Kiadó, Budapest-Pécs.

Bibó, I. (1986 [1975]): Közigazgatási területrendezés és az 1971. évi településhálózat-fejlesztési koncepció. In: Bibó István: Válogatott tanulmányok III. Magvető Kiadó, Budapest.

Binh, T. T. - Korn, U. (1996): An evolution strategy for the multiobjective optimization problems. Institute for Automation, Magdeburg.

Bourdieu, P. (1985): Az identitás és a reprezentáció. A régió fogalmának értelmezéséhez. Szociológiai Figyelö 1 (1): 7 22.

Bömermann, H. (2012): Stadtgebiet und Gliederung. Zeitschrift für amtliche Statistik Berlin Brandenburg, 1-2: 76-87. http://www.statistik-berlin-brandenburg.de/produkte/zeitschrift/2012/HZ 201201.pdf

Bunge, W. (1966): Gerrymandering, geography and grouping. Geographical Review 56 (2): 256-263.

Csanádi, G. - Ladányi, J. (1992): Budapest térbeni-társadalmi szerkezetének változásai. Akadémiai Kiadó, Budapest.

Kalyanmoy, D. (2001): Multi-objective optimization using evolutionary algorithms. John Wiley \& Sons, Chichester.

Kalyanmoy, D. - Agrawal, S. - Pratab, A. - Meyarivian, T. (2000): A fast elitist non-dominated sorting genetic algorithm for multi-objective optimization: NSGA-II. KanGAL report 200001. Indian Institute of Technology, Kanpur.

Dusek, T. (2001): A területi lehatárolások statisztikai következményei. In: Magyar Földrajzi Konferencia tudományos közleményei (CD), Szeged. 
Dusek, T. (2004): A területi elemzések alapjai (Regionális Tudományi Tanulmányok 10). ELTE Regionális Földrajzi Tanszék - MTA-ELTE Regionális Tudományi Kutatócsoport, Budapest.

Dusek, T. (2006): A térfelosztás céljai és a térgazdasági modellalkotás egyes kérdései az új gazdaságföldrajzban. In: Dietmar, M. (szerk.): Gazdag világ, szegény világ. Fejlödéselméleti koncepciók és a világgazdaság szerkezete. Tanulmányok Babanászisz Sztergiosz 70. születésnapjára. Müegyetemi Kiadó, Budapest.

Erdősi, F. (1985): Közlekedés és vonzáskörzetek. In: Faragó László - Hrubi László (szerk.): A vonzáskörzetek gazdasági és közigazgatási kérdései. MTA Regionális Kutatások Központja Dunántúli Tudományos Intézet, Pécs.

Hamed, F. - NaimiSadigh, A. - Aslanzadeh, M. (2009): Covering Problem. In: Farahani, R. Z. - Hekmatfar, M. (eds.): Facility location: Concepts, models, algorithms and case studies. Physica-Verlag, Heidelberg.

Faluvégi, A. (1994): Kistérségi területi vonzási rendszer. Statisztikai Szemle 72 (6): 496-498.

Faluvégi, A. (2012): A járások rendszere és a kistérségi beosztás. Területi Statisztika 52 (5): 421-426.

Farahani, R. Z. - Hekmatfar, M. (2009) (eds.): Facility location: Concepts, models, algorithms and case studies. PhysicaVerlag, Heidelberg.

Forest, B. (2005): The changing demographic, legal and technological contexts of political representation. Proceedings of the National Academy of Sciences of the United States of America 102 (43): 15331-15336.

Gregory, C. L. (1949): Advanced techniques in the delineation of regions. Rural Sociology 15 (1): $59-63$.

Gregory, D. - Johnston, R. - Pratt, G. - Watts, M. - Whatmore, S. (eds.) (2009): The Dictionary of human geography. Wiley-Blackwell, Chichester, West Sussex.

Grigg, D. (1969): Regions, models, classes. In: Chorley, R. J. - Haggett, P. (eds): Models in Geography. Methuen, London.

Győri, R. (2005): A történeti régió. In: Nemes Nagy József (szerk.): Régiók távolról és közelről (Regionális Tudományi Tanulmányok 12). ELTE Regionális Földrajzi Tanszék - MTA-ELTE Regionális Tudományi Kutatócsoport, Budapest.

Haggett, P. (1965): Locational analysis in human geography. E. Arnold, London

Hajdú, Z. (1987): A közigazgatási területszervezés közigazgatás-földrajzi kérdései. In: Csefkó Ferenc (szerk.): Állam, térkapcsolatok, demokrácia. Bihari Ottó emlékülés. MTA Regionális Kutatások Központja - Janus Pannonius Tudományegyetem, Pécs.

Hajdú, Z. (1994): A magyar közigazgatási területbeosztás reformjának közigazgatás-földrajzi összefüggései. In: Csefkó Ferenc (szerk.): Tér és közigazgatás. MTA Regionális Kutatások Központja - Magyar Közigazgatási Intézet, Budapest.

Hajdú, Z. (2005): Magyarország közigazgatási földrajza. Dialóg Campus Kiadó, Budapest.

Hajdú, Z. (2006): A közigazgatás kutatásának földrajzi irányzatai és a közigazgatás-földrajz módszerei. In: Pap Norbert - Tóth József (szerk.): Terület- és településfejlesztés II. Kutatások a terület- és településfejlesztésben. Alexandra, Pécs.

Ivancsics, I. - Tóth, J. (2012): A járások múltjáról és lehetséges jövőjéről. Területi Statisztika 52 (1): 6-33.

Kabai, I. (1981): A klaszterelemzés módszerei és alkalmazása. MTA Szociológiai Kutató Intézet, Budapest.

Kiss, J. P. - Bajmócy, P. (2001): Városi funkciójú központok és elméleti vonzáskörzeteik az Alföldön. Tér és Társadalom 15 (1): 65-89.

Kitchin, R. - Thrift, N. et al. (szerk.) (2009): International Encyclopedia of Human Geography. Elsevier, AmsterdamBoston-Heidelberg-London-New York-Oxford-Paris-San Diego-San Francisco-Singapore-SydneyTokyo.

Krajkó, Gy. (1989): A gazdasági térszerkezetek és a közigazgatás összefüggése. Tér és Társadalom 3 (3): $53-69$.

Kristof, L. (1959): The nature of frontiers and boundaries. Annals of American Geographers 49 (3): 269-282.

Mezencev, K. (2010): A területi egységek lehatárolásának tökéletesítése Ukrajnában az Európai Unió normái szerint. Területi Statisztika 50 (1): 56-66.

Miklóssy, E. (2011): „Város és vidéke” Erdei Ferenc és Bibó István területi-társadalomszervezési elgondolásairól. Területi Statisztika 51 (5): 511-529.

Miklóssy, E. (2012): A járás és viszontagságai. Területi Statisztika 52 (2): 102-124.

Nagy, G. (1996): A gravitációs modell alkalmazási lehetőségei a településen belüli mozgások tanulmányozására. Tér és Társadalom 10 (2-3): 149-156.

Nemes Nagy, J. (1998): A tér a társadalomtudományban. Hilscher Rezső Szociálpolitikai Egyesület, Budapest. 
Nemes Nagy, J. (szerk.) (2005): Regionális elemzési módszerek. (Regionális Tudományi Tanulmányok 11). ELTE Regionális Földrajzi Tanszék - MTA-ELTE Regionális Tudományi Kutatócsoport, Budapest.

Nemes Nagy, J. (2009): Helyek, terek, régiók. A regionális tudomány alapjai. Akadémiai Kiadó, Budapest.

Oláh, M. - Csite, A. (szerk.) (2011): Szempontok és javaslatok az alsó középszintü igazgatási terek identitás alapú kialakitásához. HÉTFA Elemzö Központ, Budapest.

Poloni, C. - Mosetti, G. - Contessi, S. (1996): Multiobjective optimization by GAs: Application to system and component design. In: ECCOMAAS (eds.): ECCOMAAS conference on numerical methods in engineering 2. John Wiley, Chichester.

Prinz, Gy. (1933): A földrajz az államigazgatás szolgálatában. Földrajzi Közlemények 61 (4-6): 69-81.

Robič, T. - Filipič, B. (2005): DEMO: Differential Evolution for Multiobjective Optimization. Lecture Notes in Computer Science 3410/2005 http://dis.ijs.si/tea/Publications/Robic05Demo.pdf (letöltve 2013. január)

Szalkai, G. (2012): A járások kialakításának módszertani megalapozása. Területi Statisztika 52 (3): 215-229.

Szalkai, G. - Jakobi, Á. (2011): A járáskialakitás térségi megalapozása-módszertan. Hétfa Elemző Központ, Budapest.

Toregas, C. - ReVelle, C. (1972): Optimal location under time or distance constraints. Papers in Regional Science 28 (1): 133-144.

Toregas, C. - Swain, R. - ReVelle, C. - Bergman, L. (1971): The Location of Emergency Services. Operations Research 19 (6): 1363-1373.

Vagács, A. (1952): Megyei központok és a közlekedés. Földrajzi Értesitö 3 (1): 183-187. 